\title{
The working hours of immigrants in Germany: temporary versus permanent
}

\author{
Martin Kahanec ${ }^{1 *}$ and Michael P Shields ${ }^{2}$
}

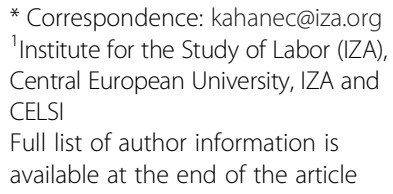

* Correspondence: kahanec@iza.org ${ }^{1}$ Institute for the Study of Labor (IZA), Central European University, IZA and CELSI

Full list of author information is available at the end of the article

\begin{abstract}
Migration is often viewed as an investment decision. Temporary migrants can be expected to invest less in accumulating human capital specific to the host country. Instead, they work more hours in order to accumulate savings and invest in financial capital that can be transferred back to their country of origin upon return. In this paper, using German panel data, we explore how temporary migrants differ from permanent migrants in their labor supply decisions and behavior. After correcting for endogeneity bias, male temporary migrants are found to work more hours than permanent ones. The effect for females is statistically insignificant.

Jel codes: J22, J61, F22

Keywords: Migration; Temporary migrants; Labor supply; Germany
\end{abstract}

\section{Introduction}

The decision to migrate, whether internal or international, is often viewed as an investment. The costs of migration, which include the physical costs of the move as well as the costs of adjusting to a new location, are incurred in order to earn higher income in the future. When exploring international migration, these adjustment costs have been viewed as the costs of adapting to the labor market in the destination country. A large part of these adjustment costs may be the costs of investing in human capital at the destination, such as becoming more fluent in a language.

Decisions regarding migration partly depend on whether the move is viewed to be permanent or temporary. One of the issues concerning temporary migration is that temporary migrants may invest less than permanent ones in human capital that is specific to the host economy. According to the human capital theory and the household production model (Becker $(1964,1965)$, the shorter the intended stay, the less such investment will be made. An example of this type of investment is learning the language of the host country. Another type of investment that is less likely to occur for temporary migrants involves job training conducted by employers. A free rider problem may be more severe for temporary migrants than for other workers in that firms may be hesitant to invest in job training for temporary migrants because they will lose the benefits of this investment when the migrant returns to the home country.

As a corollary of underinvestment in human capital specific for the host country, instead of spending time accumulating specific human capital temporary migrants can be expected to work more hours in order to accumulate savings and invest in financial capital that can

(c) 2013 Kahanec and Shields; licensee Springer. This is an Open Access article distributed under the terms of the Creative Commons Attribution License (http://creativecommons.org/licenses/by/2.0), which permits unrestricted use, distribution, and reproduction in any medium, provided the original work is properly cited. 
be transferred back to their country of origin when they return. In spite of the importance of this implication for migration and integration policy, it has received little attention in the literature. In this paper we will concentrate on the demand for migrants in Germany and the adjustments migrants make when living in Germany. We will explore temporary migration and how temporary migrants differ from permanent migrants in their labor supply decision making and behavior.

In the first section we will shed light on temporary migration and review some of the literature on behavioral differences between temporary and permanent migrants. Next, we will develop and discuss a model of temporary migration. Third, we will discuss the data and the estimation procedures to be employed in testing the model. Finally, we will discuss the conclusions implied by these estimates and some implications for policy.

\section{Temporary versus permanent migration}

Temporary migration differs from permanent migration in terms of the migrant's attachment to the labor market in the host country. The temporary migrant intends to return to the country of origin. This intention may be reinforced by contract, by immigration laws or it may simply be the intention of the migrant. Temporary migration is a common and growing phenomenon (Dustmann, 2000). Temporary migration exists when the migrant expects to return to the home country and behaves accordingly while in the host country. One type of temporary migration entails temporary residence permits which reinforce the intentions to return. Examples include temporary migration from South Asia and South-East Asia to countries in the Persian Gulf and migration from Eastern Europe to the European Union. However, temporary migration without these temporary residence permits is common in the US and in Europe. Indeed, European migration after the recent EU enlargements is predominantly temporary, at least when judged by migrants' intentions ${ }^{1}$.

Amin and Mattoo (2005) develop a model where the country receiving immigrants faces a tradeoff between the lower social costs attributed to temporary migrants and external benefits of job training which are higher for permanent migrants. They identify social costs of migration such as the provision of publicly provided services not fully supported by the tax contributions of the migrants. Temporary migrants might have lower social costs in part because they are less likely to move their family with them, thus decreasing the demand for medical, educational and social services. They also might be less of a perceived threat to a society with xenophobic issues. However, permanent migrants may invest more time assimilating to the host country. Furthermore, the skills acquired through on the job training are less likely to be lost for temporary migrants because their probability of return is higher. The authors argue that countries face a commitment problem in that they cannot credibly commit to returning temporary migrants particularly when they receive training by firms. As a result of this commitment problem, host countries restrict migration to a level below the optimum level but have too many permanent migrants.

The reduction of these social costs has become a major concern in the migration literature. Social costs can be categorized as economic costs and cultural costs. Much of the attention has focused on economic costs. Chiswick (1978) and Borjas (1987) find that assimilation does occur. Chiswick (1978) argues that gradual cultural assimilation of immigrants in the US has resulted in increased earnings. Furthermore, this assimilation came through personal investment in human capital and not from on the job training provided 
by firms because firms are reluctant to invest in training immigrants partly because they perceive a higher risk of job mobility. Borjas (1987) argues that the heterogeneity of immigrants is the source of assimilation differences and that immigrants, such as political refugees, who are more attached to the destination are the most likely to assimilate. Since temporary migrants have less attachment to the destination than permanent migrants, we would expect less assimilation.

Migration, both temporary and permanent, has had a considerable impact on the economies and cultures of industrialized nations. Germany has perhaps the most experience with assimilating migrants. From 1945 until 1960 about twelve million people of German descent migrated to West Germany ${ }^{2}$. Because these migrants were forced to move by political changes and their language was German, they were almost entirely permanent migrants and their assimilation was relatively easy. A rapidly expanding economy and a good experience in assimilating migrants resulted in a policy of bringing in new, temporary workers into Germany beginning in the 1950s. These workers were from Southern Europe and Turkey. The vast majority of these workers returned to their home country ${ }^{3}$. They were replaced by new immigrants, sometimes from the same country. This pattern of migration is called circular migration, which results in a large proportion of workers that are not native born, being temporary instead of permanent migrants.

The result of this immigration pattern is that many German immigrants are and continue to be temporary. Temporary migrants may differ from permanent migrants in many predictable ways. First, they may be expected to save more and remit more of their income. For example, Bauer and Sinning (2011) find that permanent migrants in Germany save less that native Germans. This might be because part of what they would save is invested in acquiring human capital that aids in assimilation such as learning German. Temporary migrants, however, make much less of this type of investment. The study finds that their savings were similar to that of natives and, hence, higher than permanent migrants. Their savings might have been higher than the savings of permanent migrants because of a greater desire to accumulate and transfer assets to their home country.

Another feature of temporary migration concerns home ownership. Germany has a very low rate of home ownership. According to Constant et al. (2007) only $42 \%$ of Germans own their own home compared with about $63 \%$ of Americans. Much of this low rate is probably due to the high requirements for down payments on loans in Germany. These requirements can be as high as $40 \%$ of the purchase price. Migrants, particularly temporary migrants may be expected to be much less likely to own a home than the population in general. It is not surprising that the home ownership rate for migrants is only $20 \%$. The authors find that migrants classified as having strong cultural attachments to German are much more likely to own their home, even if they also maintain strong attachments to their country of origin.

A third feature of temporary migration concerns the response to economic adversity in the destination. An adverse experience with unemployment might shorten the stay of the migrant. This might particularly be the case for migrants who come on a short-term visa. Bellemare (2007) models the dynamics of their behavior. Since migrant workers who experience high unemployment have less time to recoup lost income, their stay becomes undesirable, and they leave sooner than intended. The study points out that this is more likely to occur for unskilled workers because they face higher rates of unemployment. Hence, skilled temporary migrants might be encouraged to stay and unskilled temporary migrants might be encouraged to leave. 
A fourth feature of temporary migration, which is our primary interest, is that temporary migrants may on average work more hours than permanent migrants. Part of the reason for this higher anticipated number of hours is because they may invest less in becoming assimilated to the local labor market. This assimilation has been studied by Chiswick (1978) who found that in the US, wage rates of migrants and natives converged with time due to early investment in human capital specific to the destination labor market. Most studies have followed Chiswick (1978) in looking at earnings. For Germany, the results are mixed depending upon the design of the study. For example, Dustmann (1993) found a large and persistent earnings gap while Schmidt (1997) finds little initial gap upon accounting for education differences ${ }^{4}$.

Temporary migrants, being less interested in assimilation and more interested in accumulating assets and transferring these assets to the home country, may supply more labor. This hypothesis has received surprisingly little attention. Dustmann (1997) and Dustmann and Schmidt (2001) consider the labor supply of immigrant women. They find that these women, while receiving lower wage rates than native women, are more likely to have a full-time job. We would expect a similar manifestation of behavioral differences between temporary and permanent migrants when we look at the supply of working hours.

\section{A model of temporary migration}

The hypothesis that temporary migrants supply more hours than their permanent counterparts can be operationalized using a household production model as developed by Becker (1965). In this model the household does not receive direct utility from consuming goods. Instead, the household receives utility from consuming commodities. These commodities are produced using time and goods purchased on the market. The household receives utility from consuming these household produced commodities. The implicit prices of these commodities are derived from the household production functions. These prices will differ with the human capital of the household, other features of the background of household members and, of particular concern here, the location of the household.

Household production models have been formally extended to migration decisions by Shields and Shields (1993) and Shields (1995). In these models, the household technology differs by location. These differences are reflected in the implicit prices of commodities consumed. For example, assume the household maximizes the utility of consuming commodities at the two different locations. In other words a migrant maximizes

$$
U=U\left(Z_{D}, Z_{O}\right)
$$

Subject to

$$
I=A+w_{D} T_{D}+w_{O} T_{O}=\pi_{D} Z_{D}+\pi_{O} Z_{O},
$$

where the subscripts $D$ and $O$ represent the destination and the origin, $Z_{i}$ represents commodities consumed; $\pi_{i}$ represents the shadow price of an aggregate commodity, $w_{i}$ the wage rate and $T_{i}$ the amount of time that is spent at each location, where $i=O, D$. $O$ is the original country of the migrant and $D$ is the destination country to which the migrant has moved, in this case Germany. The person or family is assumed to have already migrated. Hence, all variables refer to future values. In this case, a permanent migrant is at a corner solution where $Z_{O}$ and $T_{O}$ are both zero. 
The household technology for producing these commodities depends on the location of the household, its human capital, where this human capital was developed and the strength of its ties to that location. Since the initial human capital of migrants was developed while they were residing in the source country, the human capital is partly specific to the source. Therefore, the implicit price of commodities would be expected to be lower at the source, particularly for recent migrants than at the destination. Consequently, we would expect that the shadow price at the destination exceeds the shadow price at the source. In other words, that

$$
\pi_{D}>\pi_{O}
$$

Furthermore, family ties to the source would be expected to further widen this difference in shadow prices because contacts with these family members may be an important commodity which the household consumes. Temporary migrants can take advantage of this difference in shadow prices. The optimal strategy might well be to temporarily migrate in order to generate savings that can then be transferred to the source when the migrant returns, where the cost of commodities is much lower than at the destination. Consumption would be suppressed at the destination because of its higher costs coupled with the desire to transfer this consumption to the source for future consumption at lower prices. A permanent move would imply higher costs of consumption for a much longer period of time and, even though it may imply higher wage rates, it could be sub-optimal.

If the motivation for a move is for higher wages, instead of for political or lifestyle reasons, the wage rate at the destination will exceed the wage rate at the origin, $w_{D}>w_{O}$. Permanent migration will be preferred to remaining at the source country if real income, evaluated in terms of shadow prices, is higher at the destination. In other words, if:

$$
w_{D} / \pi_{D}>w_{O} / \pi_{O}
$$

Higher wage rates at the destination would have to be large enough to cover higher living costs plus the costs of a move in order for a family to migrate. However, even if inequality (4) holds, the family may still prefer temporary to permanent migration. The difference in shadow prices, equation (3), provides an incentive for temporary migration. A migrant family can earn income at the destination, where income is higher, save and transfer the foregone consumption to the origin where consumption costs are lower.

To illustrate the investment nature of temporary migration, consider two time periods. The first period begins at the time the household made the migration decision. This decision involves whether to remain at the origin, to temporarily migrate or to permanently migrate. Consumption in each period is denoted as $z^{1}$ and $z^{2}$ in periods 1 and 2 . The temporary migrant consumes $z_{D}^{1}$ and $z_{O}^{2}$ in each period. The permanent migrant consumes $z_{D}^{1}$ and $z_{D}^{2}$ in each period.

This framework can be used to characterize the expected lifetime consumption of the household at the time of the migration decision. There are three possible choices. They are not to migrate, to temporarily migrate and to migrate permanently. In making this decision, the family will need to evaluate differences in the shadow prices of commodities with differences in full income. On the simplifying assumption that shadow prices and full income are the same in each period, the choices will 
amount to selecting different paths of lifetime consumption. Lifetime consumption for households that do not migrate is

$$
\begin{aligned}
& z_{O}^{1}+z_{O}^{2}, \text { where } \\
& z_{O}^{2}=I_{O} / \pi_{O}+\left[\left(I_{O} / \pi_{O}\right)-z_{O}^{1}\right](1+r)
\end{aligned}
$$

Lifetime consumption for households that permanently migrate is $z_{D}^{1}+z_{D}^{2}$, where

$z_{D}^{2}=I_{D} / \pi_{D}+\left[\left(I_{D} / \pi_{D}\right)-z_{D}^{1}\right](1+r)$

Finally, lifetime consumption for households that temporarily migrate is $z_{D}^{1}+z_{O}^{2}$, where

$$
z_{O}^{2}=I_{O} / \pi_{O}+\left[\left(I_{D} / \pi_{D}\right)-z_{D}^{1}\right](1+r)
$$

Note that the bracketed terms in (5), (6) and (7) represents savings from the first period used to augment consumption in the second period.

Since interest rates and exchange rates will influence the rate of return on savings, they will also influence the temporary versus permanent migration decision. It should be emphasized, however, that exchange rates will not be able to generate parity in the costs of commodity consumption. This is because commodities are non-tradable. They are produced, by the household, from inputs of time and goods. Even if all goods are tradable, time is not. Hence, exchange rates cannot equalize the shadow prices of commodities in the two markets, origin and destination. This is a key difference in emphasis between the household production approach and standard approaches in terms of the costs of buying goods. Exchange rate shocks, however, will still influence household decisions. While using a conventional model, Yang (2008) tests the investment nature of the savings of temporary migration. Yang (2008) argues that exchange rate shocks are a source of transitory income for families with a temporary migrant outside the source country. A deterioration in the value of a source country's currency with respect to the currency in the destination will increase the value of savings at the destination that can be remitted back to the family in the source. The study found that this windfall had a positive and significant effect on investment, in physical and human capital, at the source but had no significant impact on consumption at the source. This result would also hold for a household production approach because there would be a windfall due to the lower cost of purchasing goods when the migrant returns to the origin.

Migrants have choices regarding the types of investment they wish to make upon arriving at their destination. They can invest in human capital specific to the destination. This will increase their rate of assimilation thereby increasing the wage rate they will earn. Permanent migrants are more likely to make this sort of investment. They could alternatively accept a lower wage rate and invest in financial assets that can be transferred if they return to their home country. Temporary migrants are more likely to make this sort of investment. They would suppress the consumption of commodities in the destination and work more hours in order to transfer money for later consumption at the origin. The first type of investment is more attractive to those intending to migrate permanently and the second is more attractive to temporary migrants. Consequently, temporary migrants would 
be expected to, on average, work more hours than permanent migrants. It is this proposition that we will test in the next section.

\section{Empirical model and data}

The German Socioeconomic Panel is the main source of data for this study. It is a household-based study that annually surveys a representative sample of the German population, and has been doing so since 1984 . The study includes many socio-economic and demographic variables including variables that can be used to identify the attachment immigrants have to the German labor market. Respondents are asked about their intentions to remain in Germany. Up to and including 1995, respondents were asked if they "planned to return to their native country." After 1995 respondents were asked if they "wish to remain in Germany permanently." A dummy variable, permanent, was created (permanent $=0$ for those with a desire to either leave Germany or to return to their native country depending upon the phrasing of the question).

The hours worked by migrants in a month ${ }^{5}$ will be estimated as a function of the following variables: permanent (defined above), female (the gender of the person equals 1 if female and 0 otherwise), age, age ${ }^{2}$,years of schooling (years of formal education), and years since migration. Permanent, as discussed previously is expected to be negatively related to hours worked because temporary migrants will spend less time investing in human capital specific to the German labor market. Age and $a g e^{2}$ are related to human capital. Workers initially are expected to work more hours as they become more experienced, accumulate more relevant human capital and become more attractive to employers. Eventually, however, their mental and physical skills may diminish and they either become less able to work or more likely to retire. Consequently, we might expect age to have a positive impact on hours worked and $a g e^{2}$ to have a negative impact. The sign of married would be negative if marriage results in at least one spouse having less attachment to the labor market. Years of schooling is also assumed to represent human capital. Since education is thought to be general human capital ${ }^{6}$, it enhances the migrant's ability to adapt to changing economic conditions and to more easily maintain steady employment. Hence, years of schooling is expected to have a positive impact on hours worked. Finally, the length of time the migrant has been in Germany, years since migration, is expected to be related to human capital specific to Germany and, hence, positively related to hours worked.

Since the data set is a panel, we know the year the questions were asked. We also know the state within Germany in which the person lived in that year. The region and year are both expected to influence hours worked. Furthermore, they are both expected to influence the number of permanent versus temporary migrants. Temporary migrants may be recruited to work in areas and in years when workers are in short supply and leave when they are no longer in high demand. Consequently, the proportion of migrants who are temporary may be higher in years and states with a prosperous economy. Consequently, fixed and random time and state effects need to be considered to correct for possible biases.

Another possible source of bias comes from the likelihood that permanent is endogenous. The plans and attitudes of migrants toward remaining in Germany will in part depend upon their success in the German labor force. Those workers who experience difficulty in finding stable employment and thus work fewer hours 
than they wish may, as a result, become less attached to Germany. Consequently, the endogeneity of permanent could imply that those migrants who indicate that they are temporary work fewer hours. Recall, however, that we expected temporary migrants to supply more labor. Consequently, the endogeneity bias in a model with hours worked on the left hand side and permanent on the right hand side would be in the positive direction. Since we believe the structural direction is negative, we would expect reduced form estimates to be biased toward the null hypothesis or even lead to an incorrect sign. Hence, our main model will attempt to solve the endogeneity problem by introducing an instrumental variable.

The instrument we have chosen is whether the household reports family networks in another country. Relatives abroad is a candidate to be an instrument because it is exogenous to the labor market in Germany. The dummy variable, relatives abroad?, reporting the existence of these networks is expected to be negatively related to the attachment an immigrant feels towards Germany. It picks up the existence of relatives living abroad other than mother or father, (ex-spouse, children, siblings or grandparents) with whom the respondent has close contacts ${ }^{7}$. Those immigrants, for which relatives abroad $=1$, are expected to be less attached to Germany for numerous reasons. First, the existence of such a network might indicate an emotional attachment to another country. Second, regardless the strength of this emotional attachment, the existence of such a network provides information about another labor market and perhaps a greater opportunity of a successful move to that market. Note that for these arguments to hold it is not necessary that these relatives live in the country of immigrant's origin.

For the analysis we consider foreign born males (1,542 individuals with 13,477 observations) and females (1,024 individuals with 7,275 observations) with at least 10 and at most 350 hours worked per month, 1.5 to 300 EUR hourly wage, and 16-60 and 16-55 years of age for males and females, respectively. We prudently omit individuals who are very recent arrivals with less than one year since migration, as these might include a large share of temporary seasonal workers and posted professionals. We also disregard individuals with missing information for the considered variables.

Table 1 summarizes the key variables. We consider permanent migrants, those that do not want to stay permanently, and those that would like to return within next

Table 1 Labor supply of permanent and temporary migrants

\begin{tabular}{lll}
\hline Permanent migrants & Mean & Standard deviation \\
\hline Age & 38.70 & 10.41 \\
Percent female & 0.37 & 0.48 \\
Hourly wage & 12.30 & 8.60 \\
Monthly hours & 159.42 & 50.67 \\
\hline $\mathrm{N}$ & 10,772 & \\
\hline Temporary migrants & & 10.54 \\
\hline Age & 40.22 & 0.47 \\
Percent female & 0.33 & 8.72 \\
Hourly wage & 12.04 & 45.78 \\
\hline Monthly hours & 163.83 & \\
\hline $\mathrm{N}$ & 9,980 & \\
\hline Source: Own calculations based on GSOEP. & &
\end{tabular}


three years. We observe that hours worked decrease with tenure whereas the wage rate increases with tenure ${ }^{8}$. These raw results are in line with the theoretical model developed above. Looking at Table 1, we see that permanent migrants in Germany work an average of 159.4 hours per month. The average hours worked per week is then approximately 37 . There is considerable variation in hours worked with a monthly standard deviation that is about 50 hours per month. Temporary migrants, on the other hand, work 163.8 hours per month, i.e. 37.8 per week, with a standard deviation of 45.8. Whereas permanent migrants earn 12.3 per hour on average, the corresponding figure for temporary migrants is 12.0 . Descriptive statistics hence support the view that temporary migrants supply more hours, and earn less, than permanent ones. Let us now look at the results of the empirical strategy to see whether this finding is robust with respect to the various confounding factors.

\section{The results}

The results of the various regressions are shown in Tables 2, 3, 4, 5 and 6. Results for some explanatory variables are not reported. These include dummy variables for federal

Table 2 Hours worked by German immigrants

\begin{tabular}{|c|c|c|c|c|c|c|}
\hline & (1) & $(2)$ & $(3-1)$ & $(3-2)$ & $(4-1)$ & $(4-2)$ \\
\hline Variables & $\mathrm{FE}$ & RE & $2 S L S-1$ & $2 S L S-2$ & RE 2SLS - 1 & RE 2SLS - 2 \\
\hline \multirow[t]{2}{*}{ Permanent } & -1.199 & $-1.259^{*}$ & Dependent & $-56.24^{* * *}$ & Dependent & $-42.73^{* *}$ \\
\hline & $(0.731)$ & $(0.701)$ & variable & (16.88) & variable & (19.89) \\
\hline \multirow[t]{2}{*}{ Age } & $4.559^{* * *}$ & $4.331^{* * *}$ & -0.0019 & $3.780^{* * *}$ & 0.0024 & $3.482^{* * *}$ \\
\hline & $(0.318)$ & $(0.284)$ & $(0.0024)$ & $(0.279)$ & $(0.0026)$ & $(0.293)$ \\
\hline \multirow[t]{2}{*}{$\mathrm{Age}^{2}$} & $-0.0529^{* * *}$ & $-0.0467^{* * *}$ & -0.00003 & $-0.0488^{* * *}$ & $-0.00008^{* *}$ & $-0.0388^{* * *}$ \\
\hline & $(0.00386)$ & $(0.00353)$ & $(0.00003)$ & $(0.00354)$ & $(0.00003)$ & $(0.00398)$ \\
\hline \multirow[t]{2}{*}{ Female } & & & -0.0038 & $-36.49^{* * *}$ & & . \\
\hline & & & $(0.0067)$ & $(0.775)$ & & \\
\hline \multirow[t]{2}{*}{ Married } & $-2.674^{* *}$ & $-3.659^{* * *}$ & $-0.0518^{* * *}$ & $-7.082^{* * *}$ & $-0.0443^{* * *}$ & $-6.133^{* * *}$ \\
\hline & $(1.286)$ & $(1.146)$ & $(0.0089)$ & $(1.342)$ & $(0.0103)$ & $(1.444)$ \\
\hline \multirow[t]{2}{*}{ Years of schooling } & $1.454^{* * *}$ & $1.279^{* * *}$ & $0.0068^{* * *}$ & $1.021^{* * *}$ & $0.017^{* * *}$ & $1.946^{* * *}$ \\
\hline & $(0.379)$ & $(0.270)$ & $(0.0016)$ & $(0.210)$ & $(0.002)$ & $(0.404)$ \\
\hline \multirow[t]{2}{*}{ Years since migration } & & . & $0.0052^{* * *}$ & $0.569^{* * *}$ & & \\
\hline & 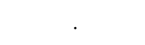 & & $(0.0005)$ & $(0.110)$ & & . \\
\hline \multirow[t]{2}{*}{ Relatives abroad } & . & & $-0.0457^{* * *}$ & . & $-0.0415^{* * *}$ & . \\
\hline & & . & $(0.0067)$ & & $(0.0074)$ & \\
\hline Children & Yes & Yes & Yes & Yes & Yes & Yes \\
\hline Federal state & Yes & Yes & Yes & Yes & Yes & Yes \\
\hline Country of origin & & . & Yes & Yes & & . \\
\hline Year & Yes & Yes & Yes & Yes & Yes & Yes \\
\hline \multirow[t]{2}{*}{ Constant } & $27.34^{*}$ & $60.24^{* * *}$ & $0.39^{* * *}$ & $108.3^{* * *}$ & $0.1802^{* * *}$ & $89.25^{* * *}$ \\
\hline & (15.82) & $(7.340)$ & $(0.058)$ & $(9.294)$ & $(0.0577)$ & (7.229) \\
\hline Wald test & & & & & 2569 & 430.48 \\
\hline F-test & & & 90.78 & 49.03 & & \\
\hline N & 20,341 & 20,341 & 20,752 & 20,752 & 20,341 & 20,341 \\
\hline
\end{tabular}


Table 3 Hours worked by German immigrant males

\begin{tabular}{|c|c|c|c|c|}
\hline & (1) & (2) & (3) & (4) \\
\hline Variables & OLS & OLS wage & RE & RE wage \\
\hline \multirow[t]{2}{*}{ Permanent } & -0.638 & -0.251 & $-1.739^{* *}$ & $-1.531^{* *}$ \\
\hline & $(0.755)$ & $(0.721)$ & $(0.789)$ & $(0.735)$ \\
\hline \multirow[t]{2}{*}{ Age } & $3.668^{* * *}$ & $4.657^{* * *}$ & $4.663^{* * *}$ & $5.921^{* * *}$ \\
\hline & $(0.257)$ & $(0.247)$ & $(0.302)$ & $(0.286)$ \\
\hline \multirow[t]{2}{*}{$\mathrm{Age}^{2}$} & $-0.0432^{* * *}$ & $-0.0548^{* * *}$ & $-0.0537^{* * *}$ & $-0.0671^{* * *}$ \\
\hline & $(0.00322)$ & $(0.00309)$ & $(0.00373)$ & $(0.00352)$ \\
\hline \multirow[t]{2}{*}{ Married } & $3.758^{* * *}$ & $5.964^{* * *}$ & 0.955 & $2.757^{* *}$ \\
\hline & $(1.042)$ & $(0.996)$ & $(1.302)$ & $(1.230)$ \\
\hline \multirow[t]{2}{*}{ Years of schooling } & $0.953^{* * *}$ & $1.551^{* * *}$ & $1.131^{* * *}$ & $1.836^{* * *}$ \\
\hline & $(0.180)$ & $(0.172)$ & $(0.282)$ & $(0.274)$ \\
\hline \multirow[t]{2}{*}{ Years since migration } & 0.0685 & $0.238^{* * *}$ & . & \\
\hline & $(0.0614)$ & $(0.0588)$ & . & \\
\hline \multirow[t]{2}{*}{ Hourly wage } & & $-1.395^{* * *}$ & & $-1.590^{* * *}$ \\
\hline & . & $(0.0386)$ & . & $(0.0349)$ \\
\hline Children & Yes & Yes & Yes & Yes \\
\hline Federal state & Yes & Yes & Yes & Yes \\
\hline Country of origin & Yes & Yes & & \\
\hline Year & Yes & Yes & Yes & Yes \\
\hline \multirow[t]{2}{*}{ Constant } & $74.01^{* * *}$ & $57.79^{* * *}$ & $63.04^{* * *}$ & $44.23^{* * *}$ \\
\hline & $(6.475)$ & (6.198) & $(7.346)$ & $(7.117)$ \\
\hline R-sq & 0.052 & 0.136 & 0.04 & 0.123 \\
\hline $\mathrm{N}$ & 13,477 & 13,477 & 13,274 & 13,274 \\
\hline
\end{tabular}

states $^{9}$, the number of children, as well as the year of survey, as they are not of primary interest in this study ${ }^{10}$. Table 2 shows results for both males and females. In addition to the explanatory variables discussed above, a dummy variable indicating gender ( 1 for females, 0 for males) is introduced in the models without fixed effects. This variable is female, which would be negatively related to hours worked if migrants follow a typical pattern where women are less attached to the labor market than men. Six different types of estimates are shown. The first column is a fixed individual effects model of monthly hours worked by immigrants in Germany. All the variables have the expected sign. It should be noted, however, that while permanent is negative, it is insignificant. This possibility was anticipated since endogeneity bias was expected to be positive while the anticipated structural effect was expected to be negative. The results for random individual effects shown in column 2 are close to the fixed effects results.

The two stages of the instrumental variable models (2SLS) without and with fixed effects are shown in the next four columns. The first stage results for the model without fixed effects are shown in column 3-1. Relatives abroad has a strong negative impact on the worker's attachment to Germany. Using relatives abroad as an instrument results in a significant and negative impact of permanent on hours worked in column 3-2. Furthermore the size of the estimated coefficient 
Table 4 Hours worked by German immigrant males

\begin{tabular}{|c|c|c|c|c|}
\hline Variables & $\begin{array}{c}(1) \\
2 S L S-1\end{array}$ & $\begin{array}{c}(2) \\
2 S L S-2\end{array}$ & $\begin{array}{c}\text { (3) } \\
\text { RE 2SLS - } 1\end{array}$ & $\begin{array}{c}(4) \\
\text { RE 2SLS - } 2\end{array}$ \\
\hline \multirow[t]{2}{*}{ Permanent } & Dependent & $-77.61^{* * *}$ & Dependent & $-46.71^{* *}$ \\
\hline & variable & $(23.34)$ & variable & $(18.71)$ \\
\hline \multirow[t]{2}{*}{ Age } & $-0.007^{* *}$ & $4.080^{* * *}$ & $-0.0054^{*}$ & $5.217^{* * *}$ \\
\hline & $(0.003)$ & $(0.379)$ & $(0.0032)$ & $(0.321)$ \\
\hline \multirow[t]{2}{*}{$\mathrm{Age}^{2}$} & 0.00002 & $-0.0531^{* * *}$ & 0.000006 & $-0.0619^{* * *}$ \\
\hline & $(0.00004)$ & $(0.00424)$ & $(0.00004)$ & $(0.00377)$ \\
\hline \multirow[t]{2}{*}{ Married } & -0.0088 & $5.336^{* * *}$ & -0.018 & $2.835^{* *}$ \\
\hline & (0.0119) & $(1.372)$ & $(0.0134)$ & $(1.324)$ \\
\hline \multirow[t]{2}{*}{ Years of schooling } & $0.0079^{* * *}$ & $2.125^{* * *}$ & $0.0188^{* * *}$ & $2.501^{* * *}$ \\
\hline & $(0.002)$ & $(0.292)$ & $(0.0026)$ & $(0.427)$ \\
\hline \multirow[t]{2}{*}{ Years since migration } & $0.005^{* * *}$ & $0.663^{* * *}$ & . & . \\
\hline & $(0.0007)$ & $(0.151)$ & . & . \\
\hline \multirow[t]{2}{*}{ Hourly wage } & $0.0008^{* *}$ & $-1.334^{* * *}$ & 0.00018 & $-1.486^{* * *}$ \\
\hline & $(0.0005)$ & $(0.0559)$ & $(0.0004)$ & $(0.0412)$ \\
\hline \multirow[t]{2}{*}{ Relatives abroad } & $-0.041^{* * *}$ & & $-0.047^{* * *}$ & \\
\hline & $(0.0084)$ & & $(0.0092)$ & \\
\hline Children & Yes & Yes & Yes & Yes \\
\hline Federal state & Yes & Yes & Yes & Yes \\
\hline Country of origin & Yes & Yes & & \\
\hline Year & Yes & Yes & Yes & Yes \\
\hline \multirow[t]{2}{*}{ Constant } & $0.499^{* * *}$ & $96.22^{* * *}$ & $0.343^{* * *}$ & $70.97^{* * *}$ \\
\hline & $(0.074)$ & $(14.34)$ & $(0.0706)$ & $(9.155)$ \\
\hline Wald test & & & 1657 & 1816.26 \\
\hline F-test & 55.19 & 19.70 & & \\
\hline $\mathrm{N}$ & 13477 & 13477 & 13274 & 13274 \\
\hline
\end{tabular}

is substantial. It indicates that workers with strong ties to the German market on average work 56 fewer hours per month than their temporary migrants. On a weekly basis, the results indicate that temporary migrants ceteris paribus work about 13 hours more than permanent migrants. The results for random effects 2SLS model in columns $4-1$ and 4-2 are similar to those without fixed effects, and so are those from a fixed effect model (not reported), although the effect of permanent stays negative but becomes statistically insignificant.

Tables 3 and 4 show estimates for males. Table 3 shows a comparison of OLS results with a random effects model. Permanent is negative in all models, but significant only in the random effect model. It is negative and marginally significant in the corresponding fixed effects model (not reported). As hourly wage rate may affect labor supply through income or substitution effect, we study the robustness of our results with respect to the inclusion of the hourly wage rate. Since there may be an endogeneity problem in introducing the hourly wage rate, results are shown both without and with this variable in Table 3. It turns out that whether or not the hourly wage rate is included in the model does not appear to have influenced the results for other variables. 
Table 5 Hours worked by German immigrant females

\begin{tabular}{|c|c|c|c|c|}
\hline & (1) & (2) & (3) & (4) \\
\hline Variables & OLS & OLS wage & RE & RE wage \\
\hline \multirow[t]{2}{*}{ Permanent } & -1.034 & -1.02 & 0.0741 & 0.468 \\
\hline & $(1.351)$ & $(1.342)$ & $(1.311)$ & $(1.267)$ \\
\hline \multirow[t]{2}{*}{ Age } & $4.114^{* * *}$ & $4.589^{* * *}$ & $3.641^{* * *}$ & $4.423^{* * *}$ \\
\hline & $(0.524)$ & $(0.523)$ & $(0.580)$ & $(0.564)$ \\
\hline \multirow[t]{2}{*}{$\mathrm{Age}^{2}$} & $-0.0516^{* * *}$ & $-0.0571^{* * *}$ & $-0.0408^{* * *}$ & $-0.0487^{* * *}$ \\
\hline & $(0.00693)$ & $(0.00690)$ & $(0.00752)$ & $(0.00730)$ \\
\hline \multirow[t]{2}{*}{ Married } & $-19.44^{* * *}$ & $-19.20^{* * *}$ & $-14.68^{* * *}$ & $-14.25^{* * *}$ \\
\hline & $(1.569)$ & $(1.558)$ & $(1.966)$ & $(1.912)$ \\
\hline \multirow[t]{2}{*}{ Years of schooling } & -0.199 & 0.219 & 0.443 & $0.912^{* *}$ \\
\hline & $(0.289)$ & $(0.290)$ & $(0.438)$ & $(0.431)$ \\
\hline \multirow[t]{2}{*}{ Years since migration } & $0.493^{* * *}$ & $0.572^{* * *}$ & & \\
\hline & $(0.109)$ & $(0.108)$ & & \\
\hline \multirow[t]{2}{*}{ Hourly wage } & & $-0.787^{* * *}$ & & $-1.501^{* * *}$ \\
\hline & & $(0.0784)$ & & $(0.0689)$ \\
\hline Children & Yes & Yes & Yes & Yes \\
\hline Federal state & Yes & Yes & Yes & Yes \\
\hline Country of origin & Yes & Yes & & \\
\hline Year & Yes & Yes & Yes & Yes \\
\hline \multirow[t]{2}{*}{ Constant } & $97.29 * * *$ & $89.35^{* * *}$ & $95.87^{* * *}$ & $84.63^{* * *}$ \\
\hline & $(11.18)$ & $(11.14)$ & (13.16) & (12.94) \\
\hline R-sq & 0.13 & 0.142 & 0.102 & 0.102 \\
\hline N & 7,275 & 7,275 & 7,067 & 7,067 \\
\hline
\end{tabular}

Models accounting for the possible endogeneity of reported permanent versus temporary migratory intentions for males are shown in Table 4. Estimates using both two stage least squares and generalized two stage least squares (i.e. with individual random effects) show that there is little difference in the results for either procedure. In addition, the coefficient of permanent is significant and of a magnitude similar to what was found in Table 2. Temporary migrant males would seem to work from 47 hours to 78 hours more per month than their permanent migrant counterparts ${ }^{11,12}$.

Tables 5 and 6 show estimates for females. The primary difference for females is there is no support for the hypothesis that temporary female migrants work more hours than permanent female migrants, whether we look at OLS, 2SLS, random effects, or fixed effects (not reported) models ${ }^{13}$.

\section{Conclusions}

After correcting for endogeneity bias, male temporary migrants are found to work more hours than their permanent counterparts. The effect is found to be statistically insignificant for female temporary migrants. This result supports a household production model of migration where migrants may be temporary by choice and not because of legal restrictions or even a bad experience in the labor market. 
Table 6 Hours worked by German immigrant females

\begin{tabular}{|c|c|c|c|c|}
\hline Variables & $\begin{array}{c}(1) \\
2 S L S-1\end{array}$ & $\begin{array}{c}(2) \\
2 S L S-2\end{array}$ & $\begin{array}{c}\text { (3) } \\
\text { RE 2SLS - } 1\end{array}$ & $\begin{array}{c}(4) \\
\text { RE 2SLS - } 2\end{array}$ \\
\hline \multirow[t]{2}{*}{ Permanent } & Dependent & -21.24 & Dependent & -36.03 \\
\hline & variable & $(23.94)$ & variable & $(122.0)$ \\
\hline \multirow[t]{2}{*}{ Age } & 0.0013 & $4.618^{* * *}$ & $0.0197^{* * *}$ & $5.144^{* *}$ \\
\hline & $(0.0046)$ & $(0.532)$ & $(0.0052)$ & $(2.470)$ \\
\hline \multirow[t]{2}{*}{$\mathrm{Age}^{2}$} & -0.00005 & $-0.0582^{* * *}$ & $-0.0003^{* * *}$ & -0.0597 \\
\hline & $(0.00006)$ & $(0.00713)$ & $(0.00007)$ & $(0.0373)$ \\
\hline \multirow[t]{2}{*}{ Married } & $-0.1053^{* * *}$ & $-21.36^{* * *}$ & $-0.059^{* * *}$ & $-16.66^{* *}$ \\
\hline & $(0.014)$ & (3.004) & $(0.0179)$ & $(7.484)$ \\
\hline \multirow[t]{2}{*}{ Years of schooling } & $0.0049^{*}$ & 0.303 & $0.011^{* * *}$ & 1.292 \\
\hline & $(0.0025)$ & $(0.311)$ & $(0.004)$ & $(1.424)$ \\
\hline \multirow[t]{2}{*}{ Years since migration } & $0.0046^{* * *}$ & $0.670^{* * *}$ & . & . \\
\hline & (0.0009) & $(0.160)$ & . & . \\
\hline \multirow[t]{2}{*}{ Hourly wage } & 0.00002 & $-0.786^{* * *}$ & 0.0007 & $-1.462^{* * *}$ \\
\hline & $(0.00069)$ & $(0.0796)$ & $(0.0006)$ & $(0.117)$ \\
\hline \multirow[t]{2}{*}{ Relatives abroad } & $-0.055^{* * *}$ & & -0.012 & \\
\hline & $(0.011)$ & . & $(0.013)$ & . \\
\hline Children & Yes & Yes & Yes & Yes \\
\hline Federal state & Yes & Yes & Yes & Yes \\
\hline Country of origin & Yes & Yes & & \\
\hline Year & Yes & Yes & Yes & Yes \\
\hline \multirow[t]{2}{*}{ Constant } & $0.286^{* * *}$ & $95.02^{* * *}$ & -0.163 & $79.22^{* * *}$ \\
\hline & $(0.098)$ & (13.14) & {$[0.12]$} & $(24.34)$ \\
\hline Wald test & & & 704 & 772.37 \\
\hline F-test & 38.36 & 19.59 & & \\
\hline $\mathrm{N}$ & 7,275 & 7,275 & 7,067 & 7,067 \\
\hline
\end{tabular}

Workers may be temporary because of strong ties to the source country that is manifested in lower costs of household production for the commodities they wish to consume.

The results provide an important example of the need to account for possible endogeneity bias in studies involving intentions, in this case the desire to remain in Germany. The results also suggest that recruiting migrants who will become assimilated easily is not necessarily welfare improving. Migrants who intend to assimilate only partially may be more motivated to succeed and to work hard. Indeed, compared to permanent immigrants, temporary immigrants have stronger attachment to the labor market, but downskilling and brain waste are of concern.

If initial perceptions differ from actual realizations (want to stay but leave; want to return but stay), suboptimal investment in country specific human capital can occur. Therefore, immigration and integration policies targeting temporary and permanent immigrants need to account for the different incentives these two groups have in host economies. 


\section{Endnotes}

${ }^{1}$ See Kahanec et al. (2010) and the evidence summarized in Kahanec and Zimmermann (2010).

${ }^{2}$ See Schmidt (1994).

${ }^{3}$ Bohning (1984) estimates that over two thirds of these workers returned.

${ }^{4}$ See Bauer et al. (2005) for a review of the literature on Germany.

${ }^{5}$ This variable is calculated from annual hours worked in the previous year reported in the GSOEP (divided by twelve to obtain average monthly hours). This underlying GSOEP variable is based on the information about employment status in the survey year, average number of hours per week, and the number of months worked in the previous year, reported in the activity calendar. This includes full-time, part-time, vocational training and short-time work, including marginal employment. The variable is not corrected for vacations or diseases.

${ }^{6}$ See Schultz (1975).

${ }^{7}$ This information was collected in 1991, 1996, 2001, and 2006. The values for the missing years are imputed backward.

${ }^{8}$ Permanent 3 is 1 for anyone who plans to stay in Germany more than 3 years, 0 otherwise.

${ }^{9}$ We distinguish West and (former) East Berlin and we merge Saarland and Rhineland-Palatinate.

${ }^{10} \mathrm{We}$ will gladly provide the complete results upon request.

${ }^{11}$ The mean and standard deviation of monthlhrs are 173.9 and 40.4 for males and 138.7 and 53.5 for females.

${ }^{12}$ We estimated the IV model for immigrant males with various years since migration. It turns out that the result that permanent migrants supply less hours holds for immigrants with less years since migration, for those with many (e.g. more than 15) years since migration the standard errors increase much beyond significance.

${ }^{13}$ This result differs from Dustmann (2000), who found that women who are temporary migrants worked more hours than men.

\section{Competing interests}

The IZA Journal of Migration is committed to the IZA Guiding Principles of Research Integrity. The authors declare that they have observed these principles.

Acknowledgments

The authors gratefully acknowledge helpful comments by the anonymous referee as well as the participants of various seminars at the Institute for the Study of Labor in Bonn. The remaining errors are ours.

Responsible editor: Denis Fougère

\section{Author details}

${ }^{1}$ Institute for the Study of Labor (IZA), Central European University, IZA and CELSI. ${ }^{2}$ Department of Economics, Central Michigan University and IZA, Mt. Pleasant, MI 48859, USA.

Received: 14 March 2013 Accepted: 18 July 2013

Published: 06 Aug 2013

References

Amin M, Mattoo A (2005) Does Temporary Migration Have to be Permanent? Policy Research. The World Bank. Working Paper Series 3582

Bauer T, Sinning M (2011) The savings behavior of temporary and permanent migrants in Germany. J Popul Econ, Springer 24(2):421-449. April

Bauer T, Dietz B, Zimmermann KF, Zwintz E (2005) German Migration: Development, Assimilation, and Labor Market Effects. In: Zimmermann KF (ed) European Migration: What do we Know? Oxford University Press, New York, pp 197-262

Becker G (1964) Human Capital. The University of Chicago Press, Chicago 
Becker GS (1965) A theory of the allocation of time. Econ J 75(299):493-517

Bellemare C (2007) A life-cycle model of outmigration and economic assimilation of immigrants in Germany. Eur Econ Rev 51(3):553-576

Bohning WR (1984) Studies in International Migration. St. Martin's Press, New York

Borjas GJ (1987) Self-selection and the earnings of immigrants. Am Econ Rev 77(4):531-553

Chiswick BR (1978) The effect of Americanization on the earnings of foreign-born men. J Polit Econ 86(5):897-921

Constant A, Roberts R, Zimmermann KF (2007) Ethnic identity and immigrant homeownership. Urban Stud 46(9):1879-1898

Dustmann C (1993) Earnings adjustment of temporary migrants. J Popul Econ 6(2):153-168

Dustmann C (1997) Differences in the labour market behaviour between temporary and permanent migrant women. Labour Econ 4(1):29-46

Dustmann C (2000) Temporary migration and economic assimilation. Swedish Econ Pol Rev 7(2):213-244

Dustmann C, Schmidt CM (2001) The Wage Performance of Immigrant women: Full-Time Jobs, Part-Time Jobs and the Role of Selection. Centre for Economic Policy Research. Working Paper 2702

Kahanec M, Zimmernann KF (ed) (2010) EU Labor Markets after Post-Enlargement Migration. Springer-Verlag, Berlin Heidelberg

Kahanec M, Zaiceva A, Zimmermann KF (2010) Lessons from Migration after EU Enlargement. In: Kahanec M, Zimmermann KF (ed) EU Labor Markets after Post-Enlargement Migration. Springer-Verlag, Berlin Heidelberg, pp 3-45

Schmidt CM (1994) The Economic Performance of Germany's East European Immigrants. Centre for Economic Policy Research. Discussion Paper 963

Schmidt CM (1997) Immigrant performace in Germany: Labor earnings of ethic Geman migrants and foreign guest-workers. Q Rev Econ Finance 37(Supplement 1):379-397

Schultz TW (1975) The value of the ability to Deal with Disequilibria. J Econ Lit 13(3):827-846

Shields MP (1995) Time, hedonic migration, and household production. J Reg Sci 35(1):117-134

Shields GM, Shields MP (1993) A theoretical and empirical analysis of family migration and household production: US 1980-1985. Southern Econ J 59(4):768-782

Yang D (2008) International migration, remittances and household investment: evidence from Philippine migrants' exchange rate shocks. Econ J 118(528):591-630

10.1186/2193-9039-2-14

Cite this article as: Kahanec and Shields: The working hours of immigrants in Germany: temporary versus permanent. IZA Journal of Migration 2013, 2:14

\section{Submit your manuscript to a SpringerOpen ${ }^{\circ}$} journal and benefit from:

- Convenient online submission

- Rigorous peer review

- Immediate publication on acceptance

- Open access: articles freely available online

- High visibility within the field

- Retaining the copyright to your article

Submit your next manuscript at $\gg$ springeropen.com 